\title{
Effects of intertidal mussel cultivation on bird assemblages
}

\author{
R. W. G. Caldow ${ }^{1, *}$, H. A. Beadman ${ }^{2}$, S. McGrorty ${ }^{1}$, M. J. Kaiser ${ }^{2}$, \\ J. D. Goss-Custard ${ }^{3}$, K. Mould ${ }^{4}$, A. Wilson ${ }^{5}$ \\ ${ }^{1}$ Centre for Ecology and Hydrology (CEH), Dorset, Winfrith Technology Centre, Winfrith Newburgh, Dorchester, \\ Dorset DT2 8ZD, UK \\ ${ }^{2}$ School of Ocean Sciences, University of Wales, Bangor, Menai Bridge LL59 5AB, UK \\ ${ }^{3} 30$ The Strand, Topsham, Exeter, Devon EX3 0AY, UK \\ ${ }^{4}$ Myti Mussels, Port Penrhyn, Bangor, Gwynedd LL57 4NH, UK \\ ${ }^{5}$ Deep Dock Limited, Bwythn Y Mor, Llanfaethlu, Holyhead, Anglesey LL65 4HD, UK
}

\begin{abstract}
Mussel Mytilus edulis cultivation on intertidal flats affects the invertebrate community, often adversely, and this may have detrimental consequences for shorebirds. Here we present the results of an experimental study to quantify the effects of intertidal mussel cultivation on shorebirds. A study area of $4.32 \mathrm{ha}$, comprising experimental plots and control plots, was laid out in summer 1999 on the mudflats of the Menai Strait in Wales. Regular counts throughout winter of 1999/2000 established pre-cultivation patterns of bird usage. Mussels were laid in the experimental plots in April 2000 and bird usage in these plots and the controls was monitored over the 2 subsequent winters. Although no species were lost from the experimental plots, the bird assemblage in them changed. This reflected variation in the distribution of the 5 most abundant species. However, none of these key species declined in abundance following the laying of mussels. Curlew Numenius arquata and redshank Tringa totanus increased in abundance, although, unexpectedly, oystercatchers Haematopus ostralegus did not. At this study site, commercial mussel cultivation may have beneficial effects, not just for the birds that eat mussels, but also for other species that can take advantage of the associated changes to the benthic fauna and habitat complexity. However, features of conservation interest at other localities may mean that bottom cultivation of mussels will have detrimental rather than beneficial effects. The environmental effects of proposals to initiate or expand bottom cultivation of mussels need to be assessed on a case-by-case basis.
\end{abstract}

KEY WORDS: Aquaculture $\cdot$ Shellfish cultivation $\cdot$ Shorebirds $\cdot$ Oystercatcher $\cdot$ Curlew $\cdot$ Redshank

Resale or republication not permitted without written consent of the publisher

\section{INTRODUCTION}

The need to determine the effects of human activities within the coastal zone has grown due to an increase in environmental awareness and the resulting legislation. This is of particular importance to the mussel Mytilus edulis growing industry because areas that are used for seabed cultivation, such as intertidal mudflats and sandflats, are specifically covered under European Habitat Conservation Regulations (Council Directive 92/43/EEC, Annex 1). Furthermore, many coastal localities in which mussel cultivation occurs are also designated under one or other (and often both) of (1) the EC Directive on the Conservation of Wild Birds (Directive 79/409) and (2) The Convention on wetlands of international importance, especially as waterfowl habitat (Ramsar Convention) (Stroud et al. 1990, Davidson et al. 1991). The mussel cultivation industry is currently the fastest growing and most valuable sector of the bivalve aquaculture industry in the United Kingdom. Therefore, it is important to establish the impact of expanding the areas of subtidal and inter- 
tidal mudflats on which mussels are laid. In this study we examine whether the cultivation of mussels on intertidal mudflats, and the density at which they are grown, has any effect on the assemblage of shorebirds that feed in such areas.

The bottom-cultivation of mussels creates very high densities of suspension-feeding bivalves that are capable of filtering large volumes of water (Smaal et al. 1986). They increase the sedimentation of particulate material (Prins \& Smaal 1994, Smaal 1994), which becomes bound with their pseudofaeces and entrapped within the mussel matrix. As a result, 'mussel mud' builds up beneath the growing mussels and the level of the whole area can become elevated. In addition, beds of bottom-grown mussels increase the topographic complexity of the environment. Thus, as the scale of cultivation increases, a larger area will be changed from being dominated by soft mineral sediments to one composed of a biogenic structure.

Several studies have demonstrated differences in the invertebrate community associated with mussel beds, compared to that of the surrounding sediments (Dittmann 1990, Guenther 1996, Commito 1997, Ragnarsson \& Raffaelli 1999, S. Durell et al. unpubl.). Asmus (1987) noted that mussel beds can be characterised by an impoverished infauna due to oxygen deficiency. Mussel beds can also support their own 'typical', highly diverse community (Dankers \& Beukema 1981, Tsuchiya \& Nishihira 1985, 1986, Ragnarsson \& Raffaelli 1999, S. Durell et al. unpubl.). In our complementary study of the effects of intertidal mussel cultivation on invertebrate communities, both the species composition and abundance of individual species were altered by the presence of mussels $(\mathrm{H}$. Beadman et al. unpubl.). Furthermore, species richness and abundance of individuals per unit area were lower where the area of mussel cover was higher (H. Beadman et al. unpubl.). Thus, both the presence of mussels, and the density at which they are grown, influence the associated invertebrate community.

Here we test the hypotheses that arise from these results. Given that laying beds of mussels on mudflats affects the invertebrate community, we test (1) that mussel cultivation will affect the shorebird assemblage; given that the effect on the invertebrate community varies with mussel density, we test (2) that laying mussels at differing densities will have different effects on the shorebird assemblage; given that oystercatchers respond positively to the laying of artificial mussel beds (Ens \& Alting 1996), we test (3) that their tendency to do so can be understood in terms of the relative profitability of feeding on such areas, as opposed to alternative feeding areas nearby.

\section{MATERIALS AND METHODS}

Study site. The study was undertaken in the Menai Strait, North Wales. The commercial mussel lays and 'wild' mussel beds lie immediately to the west of Traeth Lafan (53 $13^{\circ} 18^{\prime \prime} \mathrm{N}, 04^{\circ} 02^{\prime} 31^{\prime \prime}$ W) (Fig. 1a). This is a large intertidal area of sand- and mud-flats that qualifies as a Special Protection Area (SPA) under Article 4.2 of the EC Directive on the Conservation of Wild Birds (Directive 79/409), by supporting an overwintering population of oystercatchers of European importance (available at www.jncc.gov.uk/ukspa/ sites/Wales/UK9013031.htm). The study area was situated on the intertidal mudflats immediately to the east of Bangor pier and covered an area of 4.32 ha. At the centre of this area was a plot of $180 \times 80 \mathrm{~m}$ (Fig. 1b), in which mussels were laid. This plot comprised 2 squares, each $80 \times 80 \mathrm{~m}$ and divided into 16 cells measuring $20 \times 20 \mathrm{~m}$ each; the arrangement of each square was that of a Latin square, i. e. each treatment occured only once per row and once per column, to allow for any systematic differences. The 2 squares were separated by a strip of 4 further cells. This central plot was bounded by both upshore and downshore plots of the same dimensions (Fig. 1b) that were intended to act as control plots. To minimise the risk that human activity on the pier would disturb the birds, the whole study area was set $100 \mathrm{~m}$ away from the pier (Fig. 1b). This provided another pierside area that could act as a control plot. The plots were marked out with $1.5 \mathrm{~m}$ bamboo canes in September 1999.

Bird counts. All counts were made from Bangor Pier. As far as was possible, given the constraints of tides and daylight, the number of each species of bird in each plot, and within each cell of the central plot $(\mathrm{n}=$ 36 count units), was counted only when the study area was fully exposed. At least 1 count, but often 2 counts, were conducted per tide. All plots were counted in quick succession on each occasion. At least $30 \mathrm{~min}$ were allowed to elapse between successive counts.

Between September 1999 and March 2000, 33 counts were made on $15 \mathrm{~d}$. This data served to characterise the pre-cultivation pattern of bird usage. Following the laying of mussels in April 2000 (see below), 39 counts were made on 27 d between September 2000 and March 2001. After a further year of mussel growth, 34 counts were conducted on $21 \mathrm{~d}$ between September 2001 and March 2002. In each season, counts were conducted in each of the 7 mo on a regular basis dictated by the tidal cycle, although due to the constraints of daylight, there were less counts in each season in the months of November to January than in the other months.

Experimental mussels. In April 2000, each cell within each Latin square was seeded with mussels at 1 
of 4 densities $\left(7.5,5,3,2 \mathrm{~kg}\right.$ live weight $\left.\mathrm{m}^{-2}\right)$ as shown in Fig. 1b. A normal seeding density within this commercial system would be approximately $5 \mathrm{~kg}$ live weight $\mathrm{m}^{-2}$. The Latin squares were marked with buoys and the mussels scattered from a boat. Due to

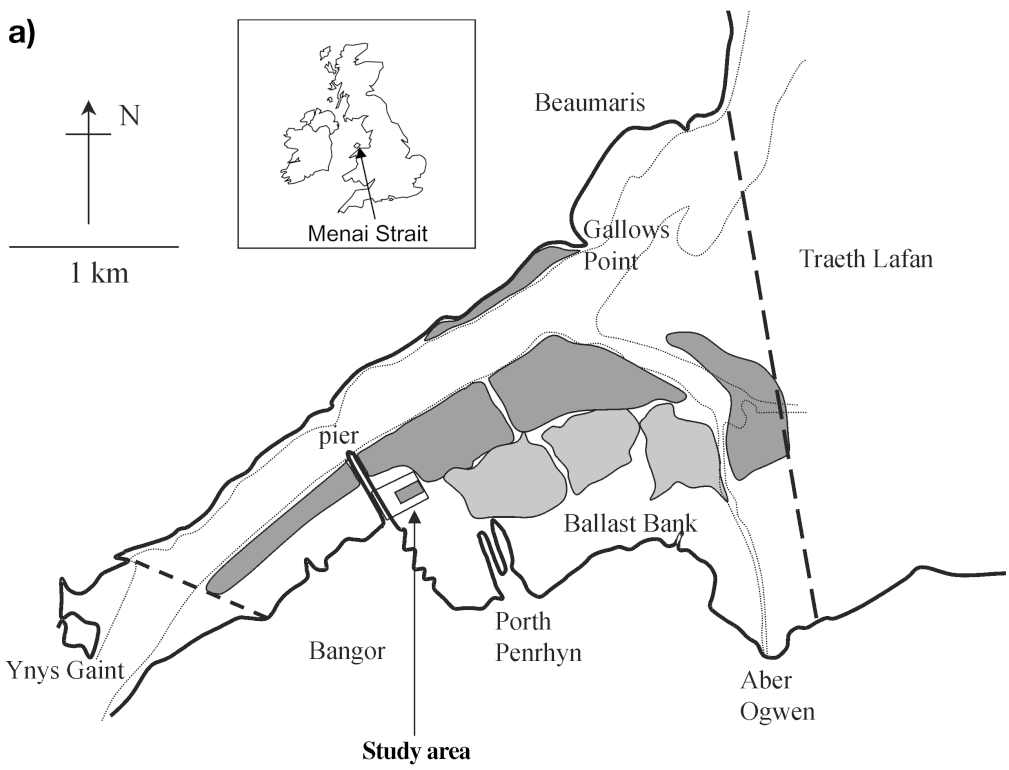

b)

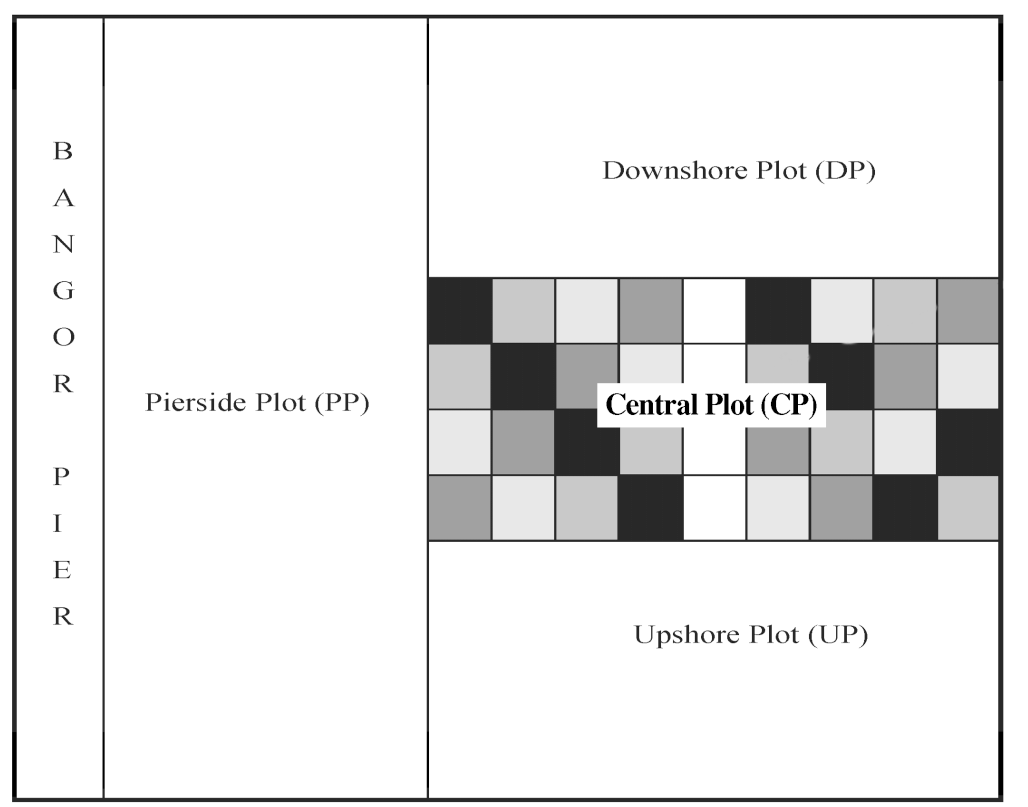

$100 \mathrm{~m}$

Fig. 1. (a) Map of the study site showing the 3 patches of 'wild' mussels Mytilus edulis (light shading), the 5 principal commercial mussel lays (dark shading) and the study area (boxed). (b) A schematic representation of the layout of the study area showing the pier, the 4 main plots and the 32 experimental cells of the 2 Latin squares in which mussels were laid at densities of

7.5 (black), 5 (dark grey), 3 (grey) and 2 (light grey) kg live weight $\mathrm{m}^{-2}$ the effects of tidal currents and boat positioning, it was not possible to lay the mussels in precise squares. Nonetheless, an a posteriori examination revealed a relatively even distribution of mussels at the designated densities. The strip of 4 cells that separated the 2 Latin squares also received some mussel cover. In addition, for commercial reasons, the downshore plot, which should have been a control plot, was also seeded with mussels in April 2000. Thus, in the final design there were 2 'experimental' plots; the central plot $(\mathrm{CP})$ comprising 36 contiguous mussel-covered cells, the downshore plot (DP), and 2 control plots; the upshore plot (UP) and the pierside plot (PP).

As part of a detailed study of mussel growth and mortality, samples of mussels were gathered from each cell of the 2 Latin squares on a regular basis between June 2000 and April 2001 (Beadman 2003). On each occasion, 4 samples of mussels (quadrat of $25 \times 25 \mathrm{~cm}$ ) were collected from random locations within each cell. All mussels within each sample were counted and measured to the nearest millimetre. The results of the surveys conducted in September 2000 and April 2001 (the last sampling date) were used to define mussel densities in the second and third study seasons, respectively.

Oystercatcher foraging. Throughout the winter of 2000/2001, observations were made of birds feeding on (1) the newly laid $\mathrm{CP}$, (2) one of the patches of 'wild' mussels and (3) 2 areas of commercial mussel lay, one immediately downshore of the study area, and the other further downshore, adjacent to the low-water springs mark. Foraging individuals were selected at random, and were watched for between 5 and $30 \mathrm{~min}$, during which the bird's feeding method (stabber or ventral hammerer, Hulscher 1996) was determined and the size of each mussel consumed was assessed. Field estimates of prey size were corrected for observer bias by a standard correction procedure (GossCustard et al. 1987). Using standard procedures (West et al. 2003), ash-free dry mass (AFDM)-length relationships for mussels were derived from samples of 40 to 50 mussels collected from each location at regular intervals throughout the winter. These relationships were used to convert 
mussel sizes into mg AFDM, and hence to derive the intake rates (mg AFDM $5 \mathrm{~min}^{-1}$ ) achieved by birds feeding in each location.

Analysis. Hypothesis 1: The count data were used to calculate an average over-winter density for each species for each season in each of the 4 plots. The PRIMER ecological statistical software package (Clarke \& Warwick 1994) was used to perform multivariate analyses of the bird assemblage data. Dissimilarities in the bird assemblages between each pair of plot $\times$ year combinations $(n=66)$ were derived using the Bray-Curtis index of dissimilarity. Non-metric multi-dimensional scaling (MDS) was then used to produce ordination axes that best represented the differences between the plot $\times$ year combinations in their bird assemblages (as represented by their Bray-Curtis dissimilarities). The average percentage contribution made by each bird species to the pairwise dissimilarities was then assessed by means of the SIMPER routine.

Because of the lack of replicates of either experimental or control plots at this scale ( $\mathrm{n}=2$ in each case), it was not possible to use the ANOSIM routine to conduct either a 1-way analysis of dissimilarities to test for overall differences between all the plot $\times$ year combinations, or pairwise ANOSIM tests between each plot $\times$ year combination. In order to conduct such tests, the count data from the $\mathrm{CP}$ were re-analysed to generate an average over-winter density for each species for each season in each of the 36 experimental units (i.e. cells) within it. These data were considered in a second set of tests in which there were 37 experimental units (36 cells of the CP plus the DP) and 2 control units (UP and PP) as before.

With the data configured in this way, the MDS analysis described above was repeated, and then 1-way analysis of dissimilarities (using ANOSIM routine) was used to test for overall differences between all treatment $\times$ year combinations. Pair-wise ANOSIM tests were then conducted between each treatment $\times$ year combination. The overall percentage contribution made by each bird species to the dissimilarities that occurred within each of the pair-wise comparisons $(n=15)$ was again analysed by means of the SIMPER routine.

All these analyses were conducted on untransformed bird densities, so that the results reflected the response of the more abundant species, rather than being biased by minor changes in the numbers of infrequently sighted species whose presence may have been incidental.

For each of the key species identified in the preceding analyses, the following regression model was fitted to the untransformed, average over-winter densities of birds in plot $i$ in season $j\left(\right.$ Dens $_{i, j}$ ) using the Generalised Linear Model (GLM) procedure of MINITAB:

$$
\text { Dens }_{i, j}=\mathrm{a}+\mathrm{b}_{i}+\mathrm{t}_{j}+\mathrm{q}\left(\mathrm{m}_{i, j}\right)
$$

This was used to test for differences between plots $\left\{b_{i}\right\}$, between seasons $\left\{t_{j}\right\}$ and, after controlling for both of these, the effect $(q)$ of the presence of mussels in the CP and DP in Seasons 2 and 3. The final variable $m_{i, j}$ has a value of 1 if mussels were present on plot $i$ in year $j$ (and 0 otherwise).

Hypothesis 2: The average over-winter density of each of the key species (identified in the previous analyses) in each of the cells of the Latin squares in each season was used to test this hypothesis. For each species, count data from the second and third seasons were analysed separately in relation to the mean density of mussels in each cell in that season, and the mean over-winter density of that species in the first season. This latter co-variate controlled for any intrinsic differences in the attractiveness of the cells evident prior to the laying of the mussels due, for example, to their proximity to the pier or their tidal exposure pattern. Analyses were conducted in this way in order to (1) avoid the possible confounding effects of differences between Seasons 2 and 3 in the birds' local population sizes, and the precise dates, times of day and heights of tides on which counts were conducted, and (2) determine whether the patterns detected in the 2 seasons were the same. Data from the 4 cells that separated the 2 Latin squares were excluded from these analyses because no data on the density or size of mussels were collected in these cells.

Hypothesis 3: The intake rates achieved by oystercatchers on the CP and those achieved in each of the other locations were compared by means of Wilcoxon Rank Sum tests in Minitab. The data for stabbers and hammerers were analysed separately.

\section{RESULTS}

\section{Hypothesis 1}

Over the course of the study, 23 bird species occurred within the study area (Table 1). All species seen in the 2 experimental plots in the first season, before they were laid with mussels, were seen at least once in those areas in the 2 following years. Thus, purely in terms of species' presence/absence from the experimental plots, the laying of mussels had no effect on the bird assemblage.

Non-metric MDS indicated, however, that although they were not identical to begin with, the bird assemblages in the 4 plots diverged over time (Fig. 2a). SIMPER analyses revealed that the top 5 species, in terms of \% contribution to the dissimilarities within each of the pair-wise comparisons, were: redshank Tringa totanus $(29 \%)$, herring gull (21\%), curlew Numenius arquata (20\%), oystercatcher (18\%), and 
Table 1. Species of birds recorded within the experimental (exp; central plot and downshore plot) and control plots (upshore plot and pierside plot) in the 3 seasons. For the 5 key species, the mean over-winter density (birds ha ${ }^{-1}$ ) across the 2 experimental plots and the 2 control plots is given for each season. For all other species, presence is indicated by +

\begin{tabular}{|c|c|c|c|c|c|c|c|}
\hline & & \multicolumn{2}{|c|}{$\begin{array}{c}\text { Season } 1 \\
1999 / 2000\end{array}$} & \multicolumn{2}{|c|}{$\begin{array}{c}\text { Season } 2 \\
2000 / 2001\end{array}$} & \multicolumn{2}{|c|}{$\begin{array}{c}\text { Season } 3 \\
2001 / 2002\end{array}$} \\
\hline & & Exp & Control & Exp & Control & Exp & Control \\
\hline Oystercatcher & Haematopus ostralegus & 5.63 & 2.27 & 6.35 & 1.09 & 9.5 & 1.78 \\
\hline Curlew & Numenius arquata & 4.07 & 1.56 & 5.73 & 2.46 & 5.88 & 2.08 \\
\hline Redshank & Tringa totanus & 5.69 & 4.19 & 5.59 & 2.31 & 6.74 & 3.1 \\
\hline Black-headed gull & Larus ridibundus & 1.51 & 1.03 & 4.1 & 1.47 & 3.1 & 1.49 \\
\hline Herring gull & Larus argentatus & 3.5 & 3.09 & 2.7 & 2.34 & 3.39 & 3.43 \\
\hline Little grebe & Tachybaptus ruficollis & & & & + & & \\
\hline Great-crested grebe & Podiceps cristatus & & & & & & + \\
\hline Cormorant & Phalacrocorax carbo & & & & + & & \\
\hline Little egret & Egretta garzetta & & & & & & + \\
\hline Grey heron & Ardea cinerea & + & + & + & + & + & + \\
\hline Mute swan & Cygnus olor & + & + & + & + & & + \\
\hline Shelduck & Tadorna tadorna & & + & + & + & + & \\
\hline Wigeon & Anas penelope & + & & + & & + & \\
\hline Mallard & Anas platyrhynchos & + & + & + & + & + & + \\
\hline Goldeneye & Bucephala clangula & & & & + & & \\
\hline Red-breasted merganser & Mergus serrator & + & + & & + & + & + \\
\hline Dunlin & Calidris alpina & + & + & + & & + & + \\
\hline Bar-tailed godwit & Limosa lapponica & & & + & & & \\
\hline Greenshank & Tringa nebularia & & + & & & + & + \\
\hline Turnstone & Arenaria interpres & & + & & + & & + \\
\hline Common gull & Larus canus & + & + & + & + & + & \\
\hline Greater black-backed gull & Larus marinus & + & + & + & + & + & \\
\hline Carrion crow & Corvus corone & + & + & + & + & + & + \\
\hline Number of species & & 14 & 16 & 15 & 17 & 15 & 15 \\
\hline
\end{tabular}

black-headed gull Larus ridibundus (10\%). These species were the most abundant and frequently sighted species in the study area (Table 1).

The results of ANOSIM analyses, in which the data from the $\mathrm{CP}$ were represented by average over-winter densities of each species in each of the 36 cells, are presented in Table 2 . There was an overall significant difference between the treatment $\times$ year combinations in the bird assemblage (ANOSIM R $=0.122$, $p$ $<0.001)$, as can be seen in the MDS ordination plot (Fig. 2b). There were no differences between seasons in the bird assemblages in the control units, but those in the experimental units differed significantly between the 2 seasons in which they had mussels, and the first one in which they did not. Within the first season, when none of the units had mussels, there was no difference between the assemblage in the experimental and control units. This may partly reflect the lack of statistical power due to the low number of control replicates in these analyses. However, in both the second and, to a lesser extent, third season in which the experimental units had mussels, there were more obvious differences between the control and experimental units. Moreover, even given the lack of control replicates, across-season comparisons between the experimental units in Seasons 2 and 3 and the control units, i.e. between areas with and without mussels, tended to show differences that were in some cases statistically significant. This was not true of the across-season comparisons between

Table 2. Pair-wise ANOSIM tests for each of the 15 pair-wise comparisons between experimental $(\mathrm{n}=37)$ and control $(\mathrm{n}=2)$ units. For each comparison, the values given are the R-statistic, and its p-value in parentheses. Values given in bold are statistically significant. E1, E2 and E3: experimental units; C1, C2 and C3: control units, in Seasons 1, 2 and 3

\begin{tabular}{|ccccccc|}
\hline C2 & $0.500(0.333)$ & & & & & \\
C3 & $-0.500(1.000)$ & $-0.500(1.000)$ & & & \\
E1 & $-0.263(0.874)$ & $0.035(0.406)$ & $-0.156(0.722)$ & $\mathbf{0 . 1 4 6 ( 0 . 0 0 1 )}$ & \\
E2 & $0.236(0.120)$ & $\mathbf{0 . 4 9 4}(\mathbf{0 . 0 1 9 )}$ & $0.355(0.050)$ & $\mathbf{0 . 1 8 0}(\mathbf{0 . 0 0 1})$ & $0.001(0.420)$ \\
E3 & $0.301(0.094)$ & $\mathbf{0 . 5 4 4}(\mathbf{0 . 0 1 1})$ & $0.380(0.051)$ & E1 & E2 \\
\hline
\end{tabular}



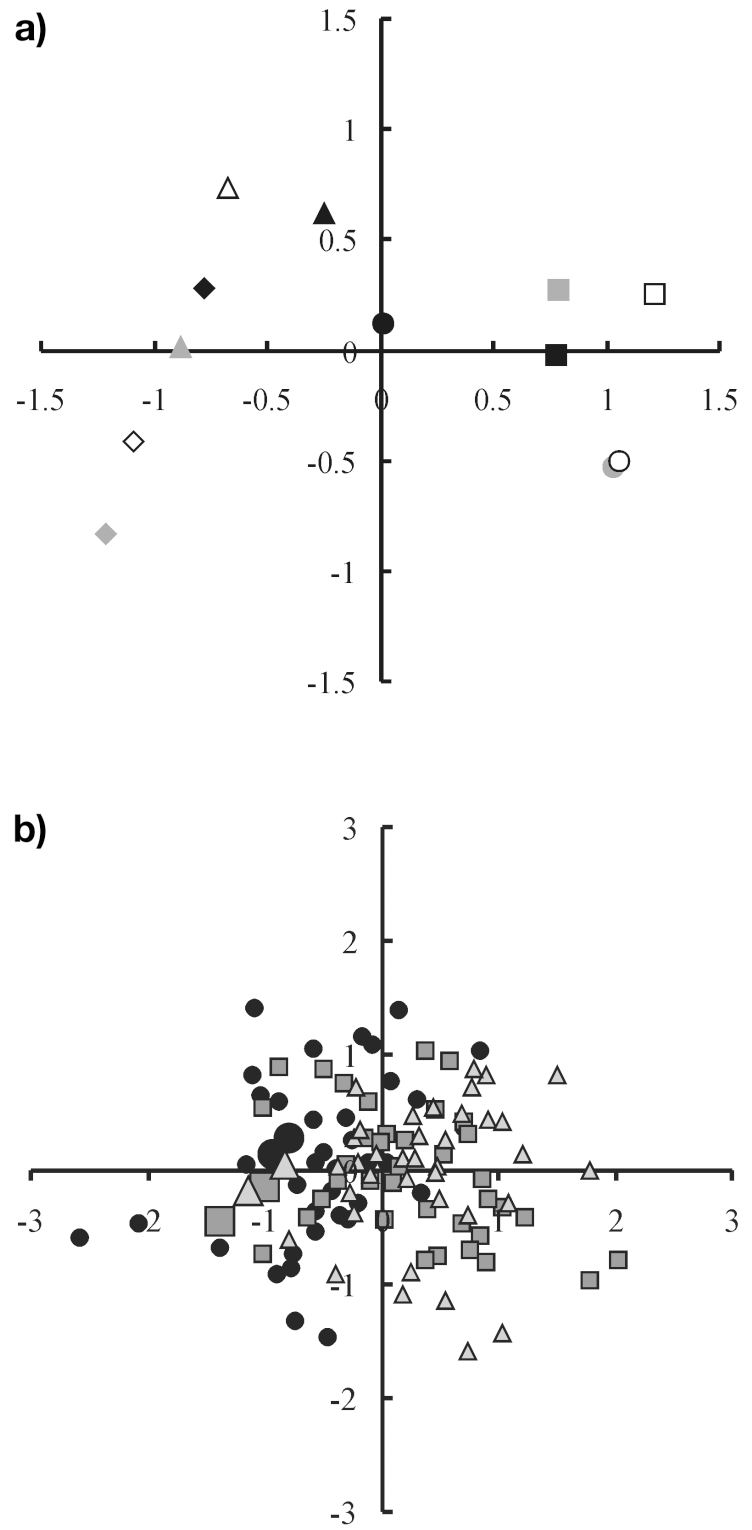

Fig. 2. (a) Two-dimensional MDS ordination of bird assemblage data in the 4 plots (central plot: circles; downshore plot: squares; upshore plot: diamonds; pierside plot: triangles) in Seasons 1 (black), 2 (grey) and 3 (open). Stress $=0.04$. (b) Twodimensional MDS ordination of bird assemblage data in the 2 control units (large symbols) and the 37 experimental units (small symbols) in Seasons 1 (circles), 2 (squares) and 3 (triangles). Stress $=0.19$

the control units in Seasons 2 and 3 and the experimental units in the first season, i.e. between areas without mussels.

SIMPER analyses of the percentage contribution of each species to the dissimilarities within each of the 15 pair-wise comparisons revealed that the same 5 species identified previously consistently explained more than $10 \%$ of the dissimilarity. Thus, all further analyses are restricted to these 5 species.
Controlling for any between-season and betweenplot differences, only the densities of curlew and redshank were significantly affected by the presence of mussels (Table 3). In both cases, densities were significantly higher where mussels were present.

In September 2000, only $11 \%$ of the mussels on the CP were longer than $40 \mathrm{~mm}$ (Fig. 3a). By April 2001 this had increased to $27 \%$ (Fig. 3b). Assuming further growth over summer 2001, the percentage of 'large' mussels would have been greater in the third season. Thus, the count data for oystercatchers were reexamined in an analysis that scored mussels as being present on the experimental plots (CP and DP) only when a substantial percentage of them would have been 'large' i.e. in only the third season. The density of oystercatchers then differed significantly between plots (highest in the 2 experimental plots), and exhibited a more positive, though still non-significant, response to the presence or absence of mussels (Table 3).

\section{Hypothesis 2}

Controlling for any effects of variation between cells in each species' distribution in the first season (a significant effect in the case of curlew), the variation in the distribution of birds between cells in the second season showed no association with the density of mussels (Table 4a). Again, controlling for the birds' distribution in the first season, only the variation in the density of redshank in the third season was associated with variation in the density of mussels between cells (Table 4a).

Given the lack of consistent, significant associations between the birds' distributions in the first season and those in the second and third seasons, the latter were re-analysed in relation to mussel density alone (Table $4 \mathrm{~b}$ ). Again, the variation in the distribution of all species between cells in the second season was not associated with variation in mussel density (Table $4 \mathrm{~b}$ ). In the third season, both redshank and oystercatcher densities showed negative associations with the density of mussels (Table 4b, Fig. 4).

\section{Hypothesis 3}

The median intake rate of 'stabbers' did not differ between those feeding on the CP and those feeding on either the 'wild' mussel bed (Wilcoxon's $W=10709$, $\mathrm{p}=0.51$ ) or on the area of commercial lay immediately downshore of the study area $(W=5137, \mathrm{p}=0.26)$. However, 'stabbers' on the CP faired significantly worse than those on the very lowest edge of a commercial lay ( $W=1768, \mathrm{p}<0.001$ ) (Table 5). The median intake rate of oystercatchers that fed by hammering mussels on 
Table 3. Generalised Linear Model (GLM) analyses of differences between seasons and plots, and controlling for these, of the presence of mussels Mytilus edulis, on the average over-winter density of the 5 principal species of shorebird. Values given for season and plot are the p-values associated with each factor, and the values given for mussels (0/1) are the p-values associated with that co-variate and, in parentheses, the value of the coefficient. Values given in bold are statistically significant

\begin{tabular}{|lccccc|}
\hline & Season & Plot & Mussels & $(0 / 1)$ \\
\hline Curlew Numenius arquata & 0.111 & $\mathbf{< . 0 0 1}$ & $\mathbf{0 . 0 4 4}$ & $\mathbf{( 1 . 0 2 9 )}$ \\
Oystercatcher Haematopus ostralegus & 0.231 & 0.124 & 0.137 & $(3.128)$ \\
Redshank Tringa totanus & $\mathbf{0 . 0 3 5}$ & 0.053 & $\mathbf{0 . 0 4 1}$ & $\mathbf{( 1 . 9 5 6 )}$ \\
Herring gull Larus argentatus & 0.483 & 0.622 & 0.849 & $(-0.242)$ \\
Black-headed gull Larus ridibundus & 0.852 & 0.121 & 0.418 & $(1.639)$ \\
Oystercatcher ${ }^{\mathrm{a}}$ Haematopus ostralegus & 0.969 & $\mathbf{0 . 0 2 2}$ & 0.095 & $(3.409)$ \\
an this case, only the central and downshore plots in Season 3 were given a \\
score of 1 for the presence/absence of mussels in order to examine oyster- \\
catchers' response to the presence of 'larger' mussels \\
\hline
\end{tabular}

the CP was significantly greater than that achieved by birds on the 'wild' bed ( $\mathrm{W}=6574, \mathrm{p}<0.01)$, did not differ from that achieved by birds on the commercial lay immediately downshore of the study area $(\mathrm{W}=1179, \mathrm{p}$ $=0.07$ ), and was significantly lower than that achieved by hammerers on the very lowest edge of a commercial lay $(\mathrm{W}=1169$, $\mathrm{p}=0.01)$ (Table 5).

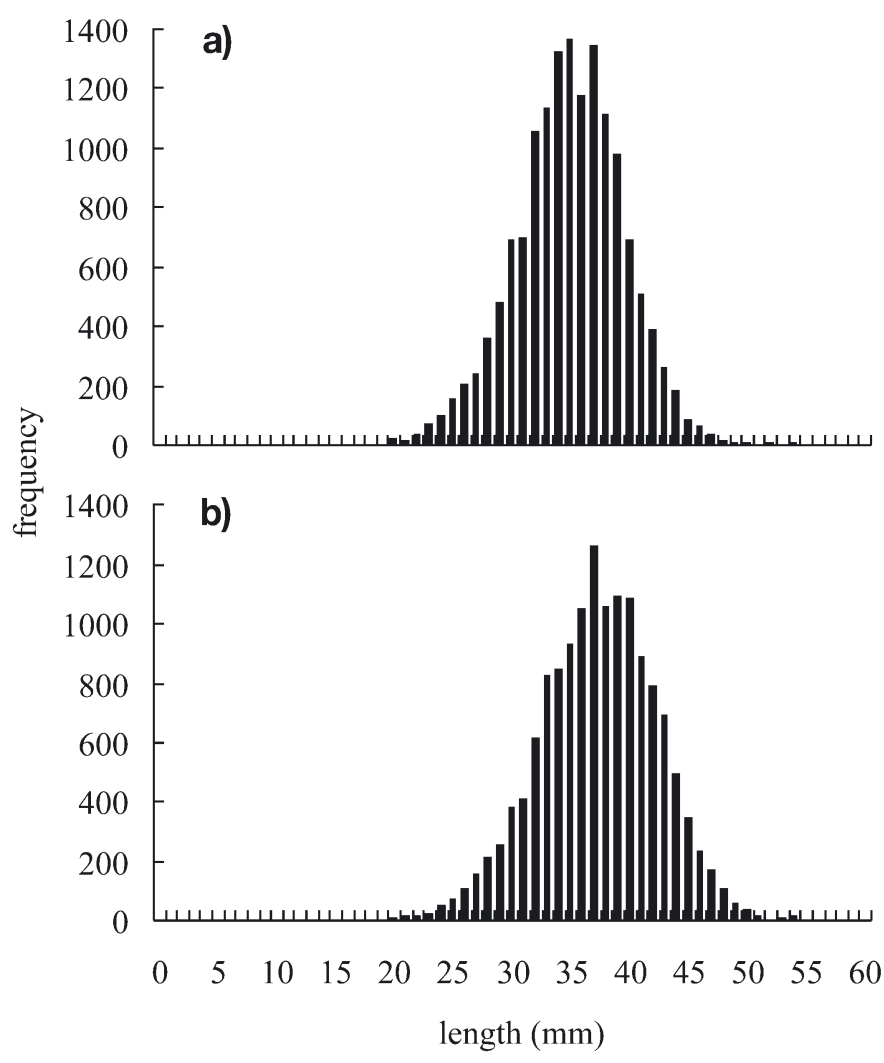

Fig. 3. Mytilus edulis. Size distribution on the central plot in (a) September $2000(\mathrm{n}=14790)$ and (b) April $2001(\mathrm{n}=14298)$

\section{DISCUSSION}

\section{Hypothesis 1}

Many previous studies (Asmus 1987, Dittmann 1990, Guenther 1996, Commito 1997, Rangarsson \& Rafaelli 1999, H. Beadman et al. unpubl.) have demonstrated that mussels affect the benthic invertebrate community of the sediment on which they grow. The results of the present study are consistent with the hypothesis that such effects give rise to changes in the associated bird assemblage.

In the first season, the assemblage in the future experimental plots was more similar to that on the adjacent control plots than subsequently. In the following 2 seasons, the bird assemblage within the 2 control plots remained relatively similar to one another, and similar to that in the first year, while that in the experimental plots, and within the CP in particular, became different from that in the first year and from that in the control plots. However, all species seen on the experimental plots in the first winter, prior to these being covered with mussels, were also seen there in the following 2 winters. The shifts in the bird assemblage reflected variation in the distribution of the 5 species most commonly found feeding on the mudflats around Bangor pier. None of these species was, however, significantly negatively affected by the laying of mussels. Indeed, the density of curlew and redshank increased significantly where mussels had been laid.

The fact that curlew and redshank, rather than oystercatchers, responded positively to the creation of the new mussel bed was surprising. However, although some species of invertebrates disappeared (e.g. Polydora antennata) and others declined in abundance once mussels had been laid (e.g. Cirratulidae, Corophium spp., Nepthys hombergii, and Notomastus latericeus), other species only appeared (e.g. Carcinus maenas and Scololepis squamata) or increased in abundance (e.g. Melita palmata, and Tubificoides benedini) on areas where mussels had been laid $(\mathrm{H}$. Beadman et al. unpubl.). Curlew and redshank may have responded to the increase in the abundance of these potential prey species, e.g. small worms ( $T$. benedini and S. squamata) and the crab C. maenas, respectively (Cramp \& Simmons 1983). Another explanation is that the mussel matrix provides a refuge from water movement and desiccation (Dittmann 1990, Ragnarsson \& Raffaelli 1999), so that invertebrates that would retreat into the sediment or otherwise become 
Table 4. Multiple regression analyses of the variation between experimental cells in the average over-winter density of each of the 5 principal shorebird species in Seasons 2 and 3 in relation to (a) the variation in the density of these species in Season 1 and in the density of mussels Mytilus edulis present in Seasons 2 and 3, and (b) solely in relation to the variation in the density of mussels present in Seasons 2 and 3. ${ }^{*} \mathrm{p}<0.05,{ }^{* *} \mathrm{p}<0.01,{ }^{* * *} \mathrm{p}<0.001$. Values of $\mathrm{R}^{2}$ in bold are statistically significant

\begin{tabular}{|c|c|c|c|c|c|c|c|c|}
\hline & \multirow[b]{2}{*}{ Constant } & \multicolumn{2}{|c|}{ Season 2 bird density } & \multirow[b]{2}{*}{$\mathrm{R}^{2}$} & \multirow[b]{2}{*}{ Constant } & \multicolumn{2}{|c|}{ - Season 3 bird density } & \multirow[b]{2}{*}{$\mathrm{R}^{2}$} \\
\hline & & $\begin{array}{c}\text { Bird } \\
\text { density } \\
\text { Season } 1\end{array}$ & $\begin{array}{l}\text { Mussel } \\
\text { density }\end{array}$ & & & $\begin{array}{c}\text { Bird } \\
\text { density } \\
\text { Season } 1\end{array}$ & $\begin{array}{l}\text { Mussel } \\
\text { density }\end{array}$ & \\
\hline (a) Curlew & 0.111 & $0.574^{* *}$ & $8.99 \times 10^{-6}$ & $0.218^{*}$ & $0.147^{*}$ & 0.196 & $5.94 \times 10^{-6}$ & 0.030 \\
\hline Oystercatcher & $0.340^{*}$ & -0.291 & $-4.30 \times 10^{-6}$ & 0.039 & $0.456^{* *}$ & 0.264 & $-4.98 \times 10^{-6}$ & 0.150 \\
\hline Redshank & $0.336^{*}$ & 0.001 & $-20.3 \times 10^{-6}$ & 0.011 & $0.553^{* * *}$ & 0.033 & $-83.5 \times 10^{-6 *}$ & $0.187^{*}$ \\
\hline Herring gull & $0.160^{* *}$ & 0.024 & $-10.1 \times 10^{-6}$ & 0.023 & $0.151^{*}$ & -0.074 & $-1.66 \times 10^{-6}$ & 0.007 \\
\hline Black-headed gull & $1 \quad 0.310$ & 0.765 & $-11.2 \times 10^{-6}$ & 0.029 & 0.153 & 0.952 & $4.38 \times 10^{-6}$ & 0.073 \\
\hline (b) Curlew & $0.246^{* *}$ & & $-10.08 \times 10^{-6}$ & 0.010 & $0.181^{* *}$ & & $2.35 \times 10^{-6}$ & 0.001 \\
\hline Oystercatcher & $0.255^{*}$ & & $7.73 \times 10^{-6}$ & 0.003 & $0.527^{* * *}$ & & $-59.81 \times 10^{-6 *}$ & $0.126^{*}$ \\
\hline Redshank & $0.336^{*}$ & & $-20.32 \times 10^{-6}$ & 0.011 & $0.565^{* * *}$ & & $-84.76 \times 10^{-6 *}$ & $0.186^{*}$ \\
\hline Herring gull & $0.163^{* *}$ & & $-10.10 \times 10^{-6}$ & 0.022 & $0.144^{*}$ & & $-2.53 \times 10^{-6}$ & 0.001 \\
\hline Black-headed gull & $1 \quad 0.364$ & & $-12.57 \times 10^{-6}$ & 0.001 & 0.244 & & $-4.37 \times 10^{-6}$ & 0.000 \\
\hline
\end{tabular}

inactive may remain closer to the surface and more active during low tide. The intake rate of redshank foraging on Corophium volutator is reduced when the latter retreat down their burrows (Selman \& Goss-Custard 1988, Stillman et al. 2000, Yates et al. 2000). Thus, although the absolute abundance of e.g. Corophium spp. was reduced in areas with mussels, this may have been offset by greater prey activity or proximity to the surface, and resulted in the maintenance or even an increase in the suitability of such areas for bird feeding.

\section{Hypothesis 2}

The effect that laying mussels has on the benthic invertebrate community depends upon the density of mussels (H. Beadman et al. unpubl.). Both the number of individuals per sample and the number of species were lower where the density of mussels was greater. The number of species was greater at low mussel densities, however, than in control areas where no mussels occurred (H. Beadman et al. unpubl.). These effects of mussel density on the benthic invertebrates had no apparent effect on the distribution of any of the 5 key bird-species in the first winter after the mussels were laid. However, in the second winter, the average overwinter density of 2 of the species that exhibited a positive response to the creation of the mussel bed (i.e. redshank and, to a lesser extent, oystercatcher) was, at the level of individual cells, negatively related to the density of mussels. These differing results, although counter-intuitive, are consistent with the hypothesis that laying mussels at differing densities has different effects on the shorebird assemblage.

The tendency for redshank to occur more frequently in cells where mussel density was lower
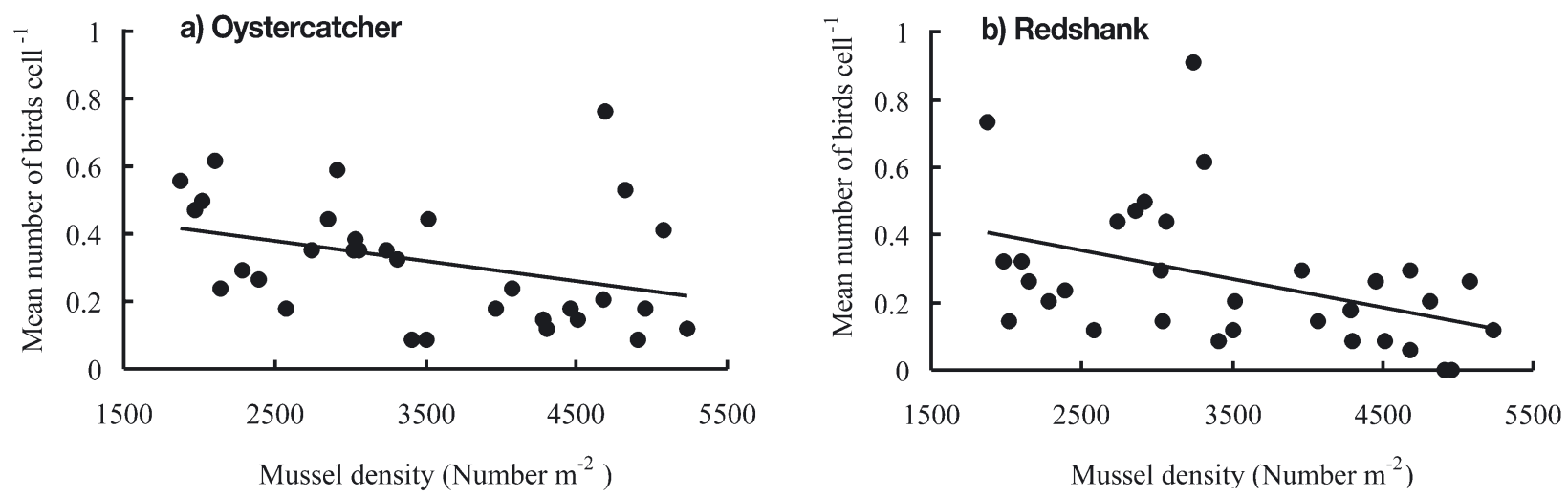

Fig. 4. Haematopus ostralegus, Tringa totanus and Mytilus edulis. Relationship between mean over-winter number of (a) oystercatchers and (b) redshank within each of 32 experimental cells in Season 3 and the density of mussels within those cells. Oystercatchers: $y=0.527-59.81 \times 10^{-6} X, \mathrm{r}^{2}=0.126, \mathrm{df}=31, \mathrm{p}<0.05$; redshank $y=0.565-84.76 \times 10^{-6} X, \mathrm{r}^{2}=0.186, \mathrm{df}=31, \mathrm{p}<0.05$ 
Table 5. Haematopus ostralegus. Intake rate (mg AFDM $5 \mathrm{~min}^{-1}$ ) of stabbing and ventral hammering birds on the experimental mussel plot in winter 2000/2001 and in 3 other nearby areas; a midshore 'wild' mussel bed (upshore of the study area), a lowshore commercial lay (downshore of the study area) and at the extreme downshore edge of a commercial lay (further downshore from the study area). In each case the median intake rate is given along with the number of 5 min periods from which this is derived, in parentheses

\begin{tabular}{|lcccc|}
\hline & $\begin{array}{c}\text { Experimental } \\
\text { plot }\end{array}$ & $\begin{array}{c}\text { Wild bed } \\
\text { (midshore) }\end{array}$ & $\begin{array}{c}\text { Commercial lay } \\
\text { (lowshore) }\end{array}$ & $\begin{array}{c}\text { Commercial lay } \\
\text { (extreme lowshore) }\end{array}$ \\
\hline Stabbers & $384(56)$ & $380(122)$ & $425(141)$ & $1008(15)$ \\
Hammerers & $493(34)$ & $380(103)$ & $634(45)$ & $673(50)$ \\
\hline
\end{tabular}

probably reflects the negative effect of mussel density on the number of invertebrate species, and on the numerical density of some species, e.g. Cirratulidae, and in particular on Corophium volutator $(\mathrm{H}$. Beadman et al. unpubl.), a preferred prey species of redshank (Goss-Custard 1977, Cramp \& Simmons 1983). Cells in which mussel density was high were covered in a solid mat of mussels that became elevated over time due to the accumulation of sediment, faeces and pseudofaces. Water draining off the higher-level mudflats tended to flow around such elevated areas, so that cells with lower densities of mussels more often contained small pools and creeks at low tide. As discussed above, it is possible that these micro-habitats, allowed invertebrates to remain active over low tide, thus enhancing the suitability of areas of low mussel density as foraging areas for species such as redshank.

\section{Hypothesis 3}

Smit et al. (1998) documented a close association over time between the variation in the numbers of oystercatchers in various parts of the Dutch Wadden Sea and the extent of intertidal mussel beds. Meire et al. (1994) noted a similar positive association in space between oystercatcher densities and the surface area of intertidal mussel beds (and cockle biomass) in various sectors of the Oosterschelde in the Netherlands. These results, and those of Ens \& Alting (1996), led us to expect that oystercatchers would exhibit the most positive response to the creation of a new patch of resources.

Oystercatchers' weak response, and the difference between this result and that of Ens \& Alting (1996), is almost certainly a function of the size of the mussels used to seed the plot, and the availability of alternative feeding grounds. In the study of Ens \& Alting (1996), mussels (of which ca. $60 \%$ were $>40 \mathrm{~mm}$ in length) were laid on an area where the staple foods for oystercatchers were Baltic tellins and ragworms Nereis diversicolor, and other mussels were rare. In contrast, our experimental mussels (of which only ca. 10\% were $>40 \mathrm{~mm}$ in length) were surrounded by 185 ha of other mussel beds. Furthermore, whereas in the study of Ens \& Alting (1996) the intake rate of the oystercatchers that fed on the mussel bed tended to exceed that of birds feeding on other prey nearby, this was not the case in our study. Thus, although our results contrast with those of Ens \& Alting (1996), they are consistent, in that in both studies, oystercatchers' response to the laying of an experimental mussel bed was dependent upon the availability and profitability of alternative food resources.

Oystercatchers' intake rates are independent of the biomass density of mussels available, unless this falls to an extremely low value $\left(<2 \mathrm{~g} \mathrm{AFDM} \mathrm{m}^{-2}\right)$ (GossCustard et al. 2001). The lowest biomass density of 25 to $60 \mathrm{~mm}$ mussels in any of the experimental cells in Year 3 was $370 \mathrm{~g} \mathrm{AFDM} \mathrm{m}^{-2}$. Thus, it is not surprising that variation in the birds' density between cells was not positively associated with that of the mussels. The negative relationship, however, arises from the negative relationship between the density and the average length of mussels within the cells (Fig. 5). Thus, in the second winter after mussels were laid, oystercatchers spent more time where the mussels were larger (Fig. 6). Although handling time increases with prey size (Zwarts et al. 1996, Beadman et al. 2003), the increase in flesh weight with increasing size is larger, so that large prey are more profitable than smaller ones (Zwarts et al. 1996, Goss-Custard et al. 2001). Had the experiment continued for another year, it is likely that the over-winter density of oystercatchers in the experimental plots would have increased substantially as their suitability improved, both in absolute terms and relative to the alternatives.

\section{CONCLUSIONS}

The curlew and the redshank, together with the oystercatcher, are the only species of wader whose populations at Traeth Lafan have surpassed the qualifying level necessary for the site to be considered of national importance for that species (Musgrove et al. 2001). Thus, in terms of the intertidal-feeding bird species of importance within the Traeth Lafan SPA, the current study suggests that the bottom cultivation of mussels is, on balance, likely to be beneficial. However, extensive bottom cultivation of mussels has occurred at this site since at least the 1960s (Dare 1980) (although the 


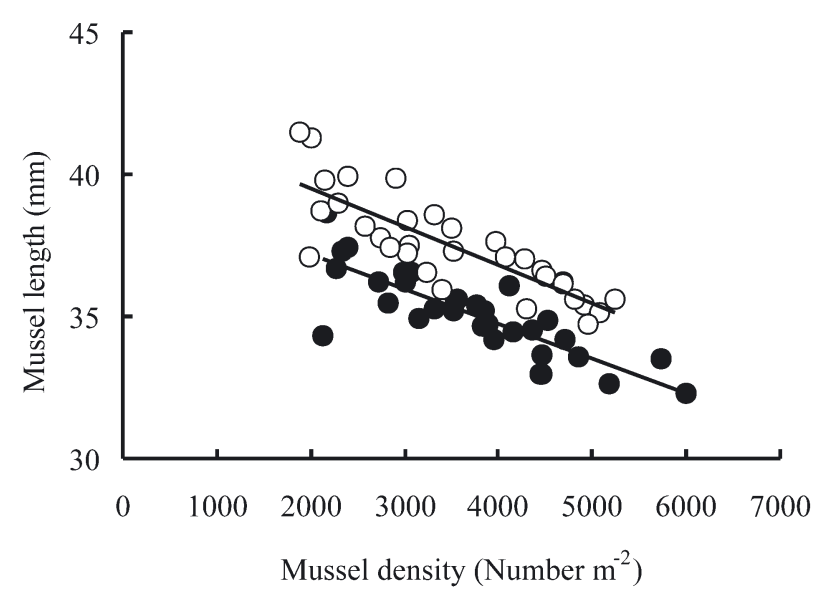

Fig. 5. Mytilus edulis. Relationship between mean length and density of mussels within each of 32 experimental cells in September 2000 (closed symbols) and April 2001 (open symbols). September 2000: $r=-0.826, p<0.001$; April 2001

$$
\mathrm{r}=-0.831, \mathrm{p}<0.001
$$

study area had not been used for this purpose previously). The bird assemblage at Traeth Lafan might to some extent have been 'selected' to be able to make use of mussel beds. The results of this study cannot, therefore, be taken as representative of the likely effects of mussel cultivation at all sites. The physical characteristics, flora and fauna at a site will influence the effect of mussel cultivation. Therefore, consideration of these features will be essential to an environmental assessment of a proposed expansion or creation of seabed cultivation plots at any other site.

This study has addressed one aspect of the environmental impact of the commercial cultivation of mussels. A full assessment of the environmental 'footprint' of an industry requires all of the processes in the production cycle to be studied. One process that, within the bivalve mariculture industry, is unique to the cultivation of mussels is the dredging of seed from wild stocks for transport to culture lots (Kaiser et al. 1998). There is very little quantitative data on which to base a scientific assessment of the effect of this practice. However, Kaiser et al. (1998) postulated that the mechanical harvesting of seed mussels is unlikely to cause major environmental change to the substratum or the associated benthic communities. Nonetheless, where extensive fisheries occur, the depletion of wild seed stocks has major effects on the trophic interactions within the system (Kaiser et al. 1998). The removal of the entire intertidal mussel stock by seed dredging in the Wadden Sea in 1990 and 1991 resulted (in association with other factors) in increased emigration and mortality of eider ducks Somateria mollissima and oystercatchers (Smit et al. 1998).

In both the Dutch Wadden Sea and The Wash in England, the (re-)establishment of intertidal mussel

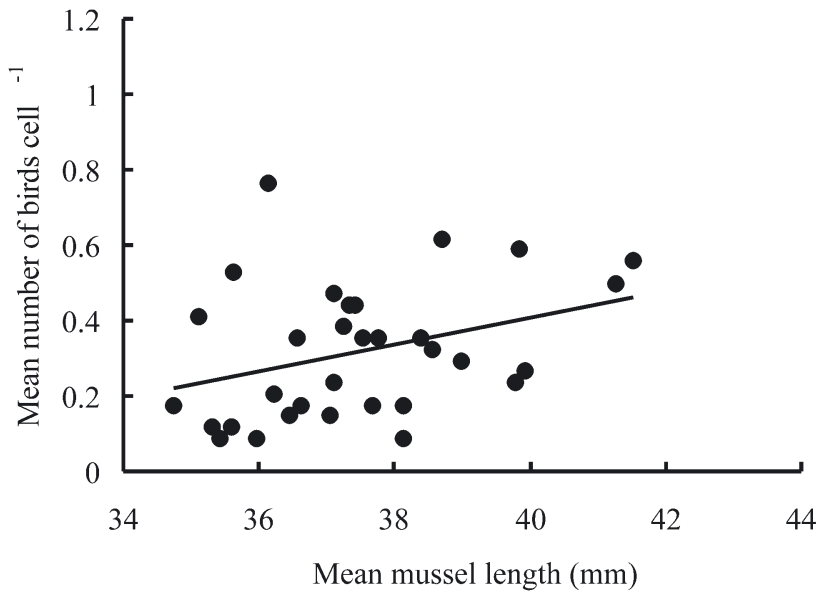

Fig. 6. Haematopus ostralegus and Mytilus edulis. Relationship between the mean over-winter (2001/2002) number of oystercatchers within each of 32 experimental cells and the mean length of mussels in April 2001: $y=-1.03+0.036 x$, $\mathrm{r}^{2}=0.122, \mathrm{df}=31, \mathrm{p}=0.05$

beds is now a key conservation target to prevent future mass mortality of these birds (Smit et al. 1998, Atkinson et al. in press). The results of the current study indicate that commercial mussel cultivation may have beneficial effects, not just for the birds that eat the mussels, but also for some other species that take advantage of the associated changes to the benthic fauna and habitat complexity. However, a balanced view must weigh any such beneficial effects against potential detrimental effects due to the harvesting of seed from wild stocks in the first place.

Acknowledgements. We would like to thank City of Bangor Council and J. Pain for permitting access to Bangor Pier at unsociable hours throughout this study, and R. T. Clarke for statistical advice. Four anonymous referees also contributed valuable comments to an earlier draft of this manuscript. This study was funded through a Natural Environment Research Council LINK-Aquaculture award ENV10.

\section{LITERATURE CITED}

Asmus H (1987) Secondary production of an intertidal mussel bed community related to its storage and turnover compartments. Mar Ecol Prog Ser 39:251-266

Atkinson PW, Clark NA, Bell MC, Dare PJ, Clark JA, Ireland PL (in press) Changes in commercially fished shellfish stocks and shorebird populations in the Wash, England. Biol Conserv

Beadman HA (2003) The sustainability of mussel cultivation. PhD thesis, University of Wales, Bangor

Beadman HA, Caldow RWG, Kaiser MJ, Willows RI (2003) How to toughen up your mussels: using mussel shell morphological plasticity to reduce predation losses. Mar Biol 142:487-494

Clarke KR, Warwick RM (1994) Change in marine communities: an approach to statistical analysis and interpretation. 
UK Natural Environment Research Council, Swindon

Commito JA (1997) Adult-larval interactions: predictions, mussels and cocoons. Estuar Coastal Shelf Sci 25:599-606

Cramp S, Simmons KEL (1983) Handbook of the birds of Europe, the Middle East and North Africa. The birds of the western Palaearctic, Vol. III. Oxford University Press, Oxford

Dankers N, Beukema JJ (1981) Distributional patterns of macrozoobenthic species in relation to some environmental factors. In: Dankers N, Kühl H, Wolff WJ (eds) Invertebrates of the Wadden Sea. Wadden Sea Working Group, Balkema, Rotterdam

Dare PJ (1980) Mussel cultivation in England and Wales. Laboratory leaflet, MAFF Directorate of Fisheries Research, Lowestoft

Davidson NC, Laffoley Dd'A, Doody, JP, Way LS and 6 others (1991) Nature conservation and estuaries in Great Britain. Nature Conservancy Council, Peterborough

Dittmann S (1990) Mussel beds - amensalism or amelioration for intertidal fauna? Helgol Meeresunters 44:335-352

Ens BJ, Alting D (1996) The effect of an experimentally created mussel bed on bird densities and food intake of the oystercatcher Haematopus ostralegus. Ardea 84A: 493-507

Goss-Custard JD (1977) Predator responses and prey mortality in redshank, Tringa totanus (L.), and a preferred prey, Corophium volutator (Pallas.). J Anim Ecol 46:21-35

Goss-Custard JD, Cayford JT, Boates JS, Durell SEA leV dit (1987) Field tests of the accuracy of estimating prey size from bill length in oystercatchers, Haematopus ostralegus, eating mussels, Mytilus edulis. Anim Behav 35:1078-1083

Goss-Custard JD, West AD, Stillman RA, Durell SEA leV dit, Caldow RWG, McGrorty S, Nagarajan R (2001) Densitydependent starvation in a vertebrate without significant depletion. J Anim Ecol 70:955-965

Guenther CP (1996) Development of small Mytilus beds and its effects on resident intertidal macrofauna. Mar Ecol $17: 117-130$

Hulscher J (1996) Food and feeding behaviour. In: GossCustard JD (ed) The oystercatcher. From individuals to populations. Oxford University Press, Oxford, p 7-29

Kaiser MJ, Laing I, Utting SD, Burnell GM (1998) Environmental impacts of bivalve mariculture. J Shellfish Res 17(1):59-66

Meire PM, Schekkerman H, Meininger PL (1994) Consumption of benthic invertebrates by waterbirds in the Oosterschelde estuary, SW Netherlands. Hydrobiologia 282/283:525-546

Musgrove AJ, Pollitt MS, Hall C, Hearn RD, Holloway SJ, Marshall PE, Robinson JA, Cranswick PA (2001) The wet-

Editorial responsibility: Otto Kinne (Editor),

Oldendorf/Luhe, Germany land bird survey 1999-2000 wildfowl and wader counts. BTO/WWT/RSPB/JNCC, Slimbridge

Prins TC, Smaal AC (1994) The role of the blue mussel Mytilus edulis in the cycling of nutrients in the Oosterschelde estuary (The Netherlands). Hydrobiologia 282/283:413-429

Ragnarsson SA, Raffaelli D (1999) Effect of mussel Mytilus edulis on the invertebrate fauna of sediments. J Exp Mar Biol Ecol 241:31-43

Selman J, Goss-Custard JD (1988) Interference between foraging redshank, Tringa totanus. Anim Behav 36: 1542-1545

Smaal AC (1994) The response of benthic suspension feeders to environmental changes. Hydrobiologia 282/283: $355-357$

Smaal AC, Verhagen JHG, Coosen J, Haas HA (1986) Interactions between seston quantity and quality and benthic suspension feeders in the Oosterschelde, The Netherlands. Ophelia 26:385-399

Smit CJ, Dankers N, Ens BJ, Meijboom A (1998) Birds, mussels, cockles and shellfish fishery in the Dutch Wadden Sea: how to deal with low food stocks for eiders and oystercatchers? Senckenb Marit 29:141-153

Stillman RA, Goss-Custard JD, Alexander MJ (2000) Predator search pattern and the strength of interference through prey depression. Behav Ecol 11 (6):597-605

Stroud DA, Mudge GP, Pienkowski MW (1990) Protecting internationally important bird sites. A review of the EEC Special Protection Area Network in Great Britain. Nature Conservancy Council, Peterborough

Tsuchiya M, Nishihira M (1985) Islands of Mytilus as habitat for small intertidal animals: effects of island size on community structure. Mar Ecol Prog Ser 25:71-81

Tsuchiya M, Nishihira M (1986) Islands of Mytilus as habitat for small intertidal animals: effects of Mytilus age structure on the species composition of the associated fauna and community organisation. Mar Ecol Prog Ser 31:171-178

West AD, Goss-Custard JD, McGrorty S, Stillman RA and 5 others (2003) The Burry shellfishery and oystercatchers: using a behaviour-based model to advise shellfishery management policy. Mar Ecol Prog Ser 248:279-292

Yates MG, Stillman RA, Goss-Custard JD (2000) Contrasting interference functions and foraging dispersion in two species of shorebird (Charadrii). J Anim Ecol 69:314-322

Zwarts L, Cayford JT, Hulscher JB, Kersten M, Meire PM, Triplet P (1996) Prey selection and intake rate. In: GossCustard JD (ed) The oystercatcher. From individuals to populations. Oxford University Press, Oxford, p 30-55

Submitted: March 24, 2003; Accepted: June 24, 2003

Proofs received from author(s): August 27, 2003 